\title{
Integrated use of biochar and lime as a tool to improve maize yield and mitigate $\mathrm{CO}_{2}$ emission: A review
}

\author{
Mehnaz Mosharrof ${ }^{1,2}$, Md. Kamal Uddin ${ }^{1 *}$, Shamshuddin Jusop ${ }^{1}$, Muhammad F. Sulaiman', \\ Shordar M. Shamsuzzaman ${ }^{2}$, and Ahmad N.A. Haque ${ }^{1}$
}

${ }^{1}$ Universiti Putra Malaysia, Faculty of Agriculture, Department of Land Management, 43400 Serdang, Selangor, Malaysia. *Corresponding author (mkuddin07@gmail.com).

${ }^{2}$ Soil Resource Development Institute, Krishi Khamar Sharak, Dhaka-1215, Bangladesh.

Received: 11 June 2020; Accepted: 23 September 2020; doi:10.4067/S0718-58392021000100109

\begin{abstract}
Reducing greenhouse gas emissions and increasing agronomic productivity by sustaining soil organic matter and refining soil fertility have become the main concerns for agricultural scientists. There is a new approach to decrease greenhouse gas emissions, soil C sinks, and improve soil quality using biochar. Soil acidification is improved by applying lime or other acid-neutralizing materials. Additionally, $\mathrm{Ca}$ and $\mathrm{Mg}$ can increase by applying lime. The availability of $\mathrm{Ca}, \mathrm{Mg}$, and $\mathrm{K}$ in the soil is significantly affected by the application rate of biochar spread separately or combined with chemical fertilizers. Soil nutrients and maize (Zea mays L.) yield are highly influenced by the use of lime and biochar. Biochar can improve the ecosystem by reducing soil $\mathrm{CO}_{2}$ emissions from agricultural practices. The inconsistent results and clarifications from various studies highlight the importance of relating the impact of different biochar rates on $\mathrm{CO}_{2}$ emissions and maize yield. This review summarizes the properties of biochar, provides the scientific reference for its application to achieve high and good quality maize and reduce $\mathrm{CO}_{2}$ emissions.
\end{abstract}

Key words: Acid soil, biochar, greenhouse gas abatement, lime, soil nutrients, Zea mays.

\section{INTRODUCTION}

Maize (Zea mays L.) is one of the leading cereal crops in the tropics, providing a source of food and oil for human beings and feed for animals along with diverse raw materials for agro-based industries (Zaidun et al., 2019). It is a vital crop worldwide and can grow in different types of soil and in a wide range of climates (Agegnehu et al., 2016). It is a very nutritious crop and provides us with phytochemical compounds and which can prevent many chronic diseases (Shah et al., 2016). The domestic production of the Malaysian maize crop was only $56000 \mathrm{t}$ in 2014, and the country imported approximately 3.2 billion tons of maize mainly from Argentina, Brazil, and India (Wahab and Rittgers, 2014). Global climate change and hunger have become crucial issues in current years. The main concern of agricultural scientists is to reduce greenhouse gas (GHG) emissions and increase agronomical fertility by increasing soil organic matter and developing soil quality (Agegnehu et al., 2016; Mandal et al., 2016; Yoo et al., 2016; Zhang et al., 2016). The largest part of solar energy radiated back into space and the anthropogenic GHGs adsorb and cause global warming (Kweku et al., 2017). The earth's temperature would be below $-18^{\circ} \mathrm{C}$ without global warming. This natural phenomenon warms the atmosphere so that life can exist on earth (Stepniewska and Kuzniar, 2013). 
The application of biochar to the soil by converting organic waste is now one of the new eco-friendly management tools worldwide (Gonzaga et al., 2018). Biochar is a C-rich organic material that has undergone the pyrolysis process of biomass thermal decomposition when heated to temperatures usually between 300 and $1000{ }^{\circ} \mathrm{C}$ under low oxygen concentrations (Domene et al., 2014). Used as a soil amendment biochar can recover soil fertility and plant growth, improve C sequestration, assist waste management, and immobilize pollutants (Jeffery et al., 2017). Biochar has a high surface area and high organic matter. It is therefore an appropriate habitat for soil micro- and macroorganisms. It can therefore increase soil biota by improving soil quality (Lehmann et al., 2011).

Liming is one of the most efficient practices to neutralize or reduce agricultural soil acidity. Moreover, lime can increase the availability of $\mathrm{Ca}$ and $\mathrm{Mg}$ in soils (Joris et al., 2013). Lime can be applied to the surface or incorporated into the soil by tillage. Many studies have verified that surface application does not involve any problems for the soil; therefore, it is the most suitable scheme for lime application under no-tillage management (Yagi et al., 2014). Liming material can reduce acidification by increasing soil $\mathrm{pH}$ and $\mathrm{Ca}^{2+}$ concentration and by decreasing $\mathrm{Al}$ toxicity in the field (Shaaban et al., 2015).

In acidic soil, $\mathrm{Al}$ toxicity is one of the main restrictions on crop productivity, and $40 \%$ of worldwide arable land is affected. In Malaysia, phytotoxicity of the $\mathrm{Al}$ ion $\left(\mathrm{Al}^{+3}\right)$ and low $\mathrm{pH}$ are the two main aspects affecting maize production in tropical acidic soils (Rabileh, 2014). Nigussie et al. (2012) demonstrated that using $10 \mathrm{t} \mathrm{ha}^{-1}$ of maize stalk biochar can increase soil $\mathrm{pH}$ by $9 \%$. This increase in soil $\mathrm{pH}$ was due to the unique properties of biochar, such as its large surface area and porosity characteristics. As a result these two features increase soil cation exchange capacity (CEC), which is a consequence of the opportunity for $\mathrm{Al}$ and $\mathrm{Fe}$ to bind with the soil exchange sites; therefore, biochar applied to the soil reduces exchangeable $\mathrm{Al}$ and $\mathrm{Fe}$. Syuhada et al. (2016) proved that the accessibility of $\mathrm{K}, \mathrm{Ca}$, and $\mathrm{Mg}$ in the soil significantly changed with the biochar rate when biochar was used, whether it was spread separately or mixed with inorganic fertilizer. Sorghum plant height increased by $20.1 \%$ and $13.7 \%$ after being treated with $5 \%$ and $10 \%$ biochar, respectively, compared with untreated soil (Ibrahim et al., 2020). When using four biochar rates, they also found that the $5 \%$ rate provided the best outcome for forage sorghum. According to Nigussie et al. (2012), soil CEC increased by $30 \%$ due to applying biochar to the soil. Cornelissen et al. (2013) reported an undisputable result when they detected a substantial enhancement of soil CEC by applying biochar in a maize farming location in Zambia. Biochar and lime application can positively influence maize yield and soil nutrients (Somchai et al., 2014). Plants can grow in a wide range of $\mathrm{pH}$, but the ideal $\mathrm{pH}$ range is from 5.5 to 7.0 for healthy plant growth (Leonard, 2012). Soil enzyme activity was affected by the two main features of soil total $\mathrm{N}$ and exchangeable $\mathrm{Ca}$. Biochar application has decreased soil exchangeable $\mathrm{Ca}$ and intensified soil organic C (SOC), exchangeable K, and total N (Xiubin et al., 2015). Njoku et al. (2016) observed a significant $(\mathrm{P}<0.05)$ increase in maize height and grain yield with the biochar treatment compared with the control. Soil microorganisms, rooting patterns, soil aeration, water holding capacity, and bulk density were altered by applying biochar (Zafar et al., 2018). According to Asmare and Markku (2016), there are two essential features, phytotoxicity of soluble $\mathrm{Al}$ and $\mathrm{Mn}$ and an inadequate amount of trace elements, such as $\mathrm{Ca}, \mathrm{K}, \mathrm{Mg}, \mathrm{P}$, and $\mathrm{Mo}$, which are responsible for preventing the productivity of acidic soils. Generally, $\mathrm{N}$ in biochar is a heterocyclic compound, and plants cannot uptake it as an available form. As a result, total $\mathrm{N}$ cannot significantly modify mineral $\mathrm{N}$ to the soil by applying biochar (Zhang et al., 2011). The $\mathrm{H}^{+}$concentrations increased by the extreme practice of $\mathrm{N}$ fertilizers, which account for soil acidity (Shaaban et al., 2016). This review focuses on the enhancement mechanism of maize yield and the decrease of $\mathrm{CO}_{2}$ emissions by applying biochar and lime.

\section{Nutritional value of maize}

Maize is the leading staple food for humans in South America, Africa, and some parts of Asia and serves as livestock feed worldwide. In recent years maize has been the source of quality protein, which can play a significant role in reducing global vitamin A shortage and protein-energy malnourishment (Kumar and Jhariya, 2013). It can provide an energy

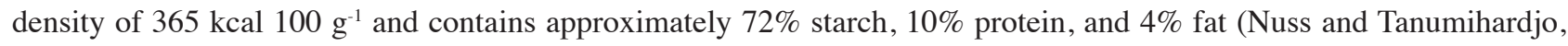
2010). The maize kernel provides approximately $70 \%$ of its weight as starch, which is the main dietary element. It also includes oil for human beings, which can decrease blood cholesterol (Kumar and Jhariya, 2013). Vitamin A as provitamin A carotenoids and vitamin $\mathrm{E}$ as tocopherols are the main components of fat-soluble vitamins originating from common yellow maize kernels (Nuss and Tanumihardjo, 2010). The third largest nutritional element of the kernel is fat along with 
starch and protein, which can be found as oil and ranges from 3.5\% to $6.0 \%$ of total kernel weight. This oil is used for cooking and in salads (Shah et al., 2016).

\section{Biochar production and characterization}

Biochar can be used as a modifier or conditioner for organic farming and recover soil productivity. Biochar has been developed from terra preta from the Brazilian Amazon. It is a C-rich organic material made by the pyrolysis process at relatively high temperatures $\left(300\right.$ to $700{ }^{\circ} \mathrm{C}$ ) and in the presence of low oxygen (Lehmann and Joseph, 2009). The residual biomass such as manure, crop residues, wood residues, forest, green and agricultural wastes such as straw, sawdust, husks, seeds, nutshells, peels, bark, bagasse, wood shavings, animal beds, corn cobs, and corn stalks, industrial wastes such as bagasse, distillers grain, and urban or municipal wastes are widely used to produce biochar (Novotny et al., 2015). Waste management also occurs while producing and using biochar (Kameyama et al., 2016).

The biochar characteristics depend on which materials are used and the process used for conversion (Figure 1). Biochar physical properties positively influence soil health because it is a way to control the living world (Ajema, 2018). Biochar characteristics vary depending on the pyrolysis process and feedstock (Bird, 2015). The type of soil and the biochar physicochemical properties can determine the biochar rate and application technology. Han et al. (2019) studied Mollisols soils in China and found that soil available P was affected by the types of feedstock and pyrolysis temperatures during biochar production. A large specific surface area and microporosity are unique properties of biochar. They are related to temperature and when temperature increases, these two characteristics of biochar also increase. Pore-size distributions, particle density, and surface area are the physical characteristics of biochar. However, $\mathrm{pH}$, total $\mathrm{C}$, and total $\mathrm{N}, \mathrm{P}$, exchangeable cations, acid neutralizing capacity, CEC, conductivity, and designated nutrient and contaminant trace elements are its important chemical characteristics (Agegnehu et al., 2016).

\section{Biochar as soil amendment}

The primary concerns in promoting the innovation of the cultivation system are food safety, restored soil productivity, sustainable crop production, and global warming. Biochar is progressively becoming an option approved by scientists and policymakers because of its prospective ability to reduce GHG emissions, C sequestration, waste mitigation, renewable energy, and as soil amendment (Beesley et al., 2011). Biochar has two unique features that make it superior to all other organic materials. The first and foremost is its high stability against decomposition. It can exist for an extended period in the soil and provides it with long-term benefits. It also defines the long-term impact of GHG emissions from the pedosphere and contributes to the mitigation of global warming. The potential for nutrient retention is the second important quality of biochar (Mensah and Frimpong, 2018). Furthermore, biochar-amended soil assists nutrient uptake for adequate plant growth by maintaining root growth and biomass and the root/shoot ratio (Zhu et al., 2018).

Figure 1. Biomass sources and conversion methods to obtain final products (Beluri et al., 2018).

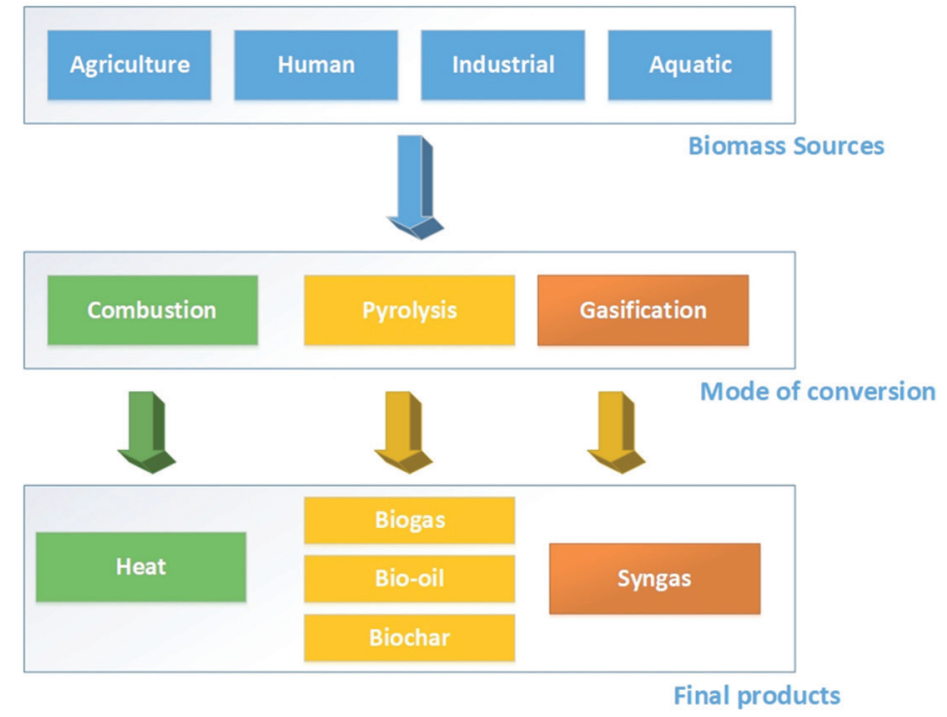




\section{Impact of biochar on greenhouse gases (GHGs) and microbial activity}

Biochar has been foreseen as a new opportunity for the mitigation of GHG emissions, C sequestration, and crop yield expansion (Jeffery et al., 2011). Biochar has the potential to address the problems of global climate change by raising the stable organic matter fraction, which is known as SOC (Sohi et al., 2010; Atkinson et al., 2010). According to Ventura et al. (2013), biochar can decrease nutrient leaching from the soil and GHG emissions (Kammann et al., 2012; Cayuela et al., 2013). Biochar can mitigate climatic change by increasing soil $\mathrm{C}$ because it is a solid charcoal-like material (Lal, 2011). According to Zhang et al. (2011), the application of biochar decreased $\mathrm{N}_{2} \mathrm{O}$ emissions while $\mathrm{CH}_{4}$ emissions increased. The emission of $\mathrm{N}_{2} \mathrm{O}$ from ruminant urine patches decreased $\mathrm{N}$ by $50 \%$ with a combination of $30 \mathrm{t} \mathrm{ha}^{-1}$ biochar (TaghizadehToosi et al., 2011). Cayuela et al. (2014) reported that soil $\mathrm{N}_{2} \mathrm{O}$ emissions decreased by $54 \%$ on average in laboratory and field experiments using different biochar feedstocks between 2007 and 2013. Meanwhile, the emission of $\mathrm{N}_{2} \mathrm{O}$ increased in a rice field when applying biochar (Shen et al., 2014).

Different types of living things, including bacteria, fungi, nematodes, protozoa, arthropods, and earthworms, are the essential microorganisms that significantly contribute in an eco-friendly environment. By making space for soil microorganisms, soil microbial respiration increased along with soil density, and soil biodiversity increased by applying biochar (Slapakova et al., 2018). The application of biochar substantially contributes in influencing soil microbes, increasing microbial activity, and biomass (Thies and Rillig, 2009).

\section{Influence of lime on greenhouse gases, yield, and nutrient availability}

The application of chemical fertilizers, such as $\mathrm{N}$ fertilizer, has increased $\mathrm{N}_{2} \mathrm{O}$ emissions. In contrast, the application of dolomitic limestone has decreased $\mathrm{N}_{2} \mathrm{O}$ emissions (Shaaban et al., 2016). The emission of cumulative $\mathrm{N}_{2} \mathrm{O}$ was markedly reduced between $4.6 \%$ to $32.7 \%$ in an experiment with either the separate or combined use of biochar and dolomitic limestone, whereas cumulative $\mathrm{CO}_{2}$ emissions increased when applying both biochar and dolomitic limestone. In this case, biochar was the only relevant amendment (Oo et al., 2018).

Liming is a well-known agricultural technique to improve soil acidification. Organic matter mineralization, nitrification, denitrification, and soil $\mathrm{N}$ transformation are significantly influenced by lime (Bolan et al., 2011; Shaaban et al., 2014). The concentrations of soil available $\mathrm{P}$ and alkali dissolved $\mathrm{N}$ decreased when applying lime (Yao et al., 2019). One of the limiting factors for maize production is soil acidity. In a study by Mwangi et al. (2000) in a Kenyan acidic soil, maize yield increased significantly $\left(6.68 \mathrm{tha}^{-1}\right)$ with lime-treated soil compared with untreated soil. Similarly, a significant increase in maize yield was found by Opala et al. (2018). According to Onwuka et al. (2009), maize production using $8 \mathrm{t} \mathrm{ha}^{-1}$ calcium carbonate significantly $(\mathrm{P}<0.05)$ increased soil $\mathrm{pH}$ from 5.20 to 8.04 . In contrast, for different liming elements using $8 \mathrm{t} \mathrm{ha}^{-1}, \mathrm{pH}$ varied between 6.05 and 6.55. Soluble $\mathrm{P}$ forms a complex with $\mathrm{Ca}$ when soil $\mathrm{pH}$ is $>6$ for the high lime rate and results in decreased available $\mathrm{P}$. However, when $\mathrm{pH}$ is low, a low lime rate is inadequate to remove soluble $\mathrm{Al}$ and $\mathrm{Fe}$, which fix P (Opala, 2017).

\section{Effect of biochar on global warming and $\mathrm{CO}_{2}$ emissions}

The $\mathrm{CO}_{2}$ emissions from agronomic soil are responsible for their ecological impact. As a result, $\mathrm{C}$ sequestration in soils is reduced, and the final consequence is global climate change (Dhadli and Brar, 2016). In 2014, $\mathrm{CO}_{2}$ emissions accounted for $81 \%$ of total emissions, methane for $10.6 \%, \mathrm{~N}_{2} \mathrm{O}$ for 5.6\%, and F-gases for 2.9\% (Kijewska and Bluszcz, 2016). In the $1800 \mathrm{~s}$, the concentration of $\mathrm{CO}_{2}$ emissions was approximately $280 \mathrm{ppm}$, whereas it now accounts for approximately $400 \mathrm{ppm}$. Since the start of the Industrial Revolution until today, atmospheric $\mathrm{CO}_{2}$ concentrations have increased by more than $40 \%$ (EPA, 2009-2012). The concentration of GHGs, mainly $\mathrm{CH}_{4}, \mathrm{CO}_{2}$, and $\mathrm{N}_{2} \mathrm{O}$, in the environment has significantly increased due to human actions, for example, applying different types of chemicals in agriculture, debris from incineration processes, bushfires, and other manufacturing activities (Kweku et al., 2017). It has been predicted that the $\mathrm{CO}_{2}$ concentration will increase by $30 \%$ to $150 \%$ by 2100 (Belic, 2006).

Greenhouse gases, such as $\mathrm{CO}_{2}$ and $\mathrm{N}_{2} \mathrm{O}$ emissions, have a substantial effect on global climate change and environmental chemistry. Biochar application is a possible option to decrease $\mathrm{GHG}$ emissions through $\mathrm{C}$ capture and $\mathrm{N}_{2} \mathrm{O}$ mitigation (Wu et al., 2018). Biochar created from the thermochemical alteration of living matter subjected to the presence of low oxygen (Sohi et al., 2010) is responsible for the successful outcome of reducing $\mathrm{CO}_{2}$ and $\mathrm{N}_{2} \mathrm{O}$ emissions (Lehmann et al., 2011; Cayuela et al., 2014). However, for individual biochar and various soil categories, there are different types of 
effects reduced GHG emissions (Taghizadeh-Toosi et al., 2011). Both He et al. (2016) and Song et al. (2016) indicated substantial increases in $\mathrm{CO}_{2}$ emissions, $19 \%$ and $22 \%$, respectively, while Liu et al. (2013) found nonsignificant effects of biochar on soil $\mathrm{CO}_{2}$ emissions. The $\mathrm{CO}_{2}$ emissions increase due to the mineralization of SOC when applying biochar (Luo et al., 2011; Cely et al., 2014). In contrast, decreased $\mathrm{CO}_{2}$ emissions resulted from the prevention of SOC mineralization (Kuzyakov et al., 2009; Singh and Cowie, 2014). Biochar application can inhibit soil $\mathrm{CO}_{2}$ emissions produced under temperatures between 400 and $510{ }^{\circ} \mathrm{C}$ (Spokas and Reicosky, 2009). Soil respiration is restricted by biochar application during maize cultivation (Liu et al., 2011; Shen et al., 2017) due to the labile C sorption from the large surface area and porous characteristics of the biochar (Lehmann et al., 2011). According to Weng et al. (2017), rhizodeposits absorbed by biochar and enzymes in the soil inhibit microbial activity, which is responsible for soil $\mathrm{C}$ degradation. Thus, $\mathrm{CO}_{2}$ emissions decreased using biochar soil.

\section{Aluminum toxicity and nutrient availability}

In the field environment, there was an interactive consequence on soil nutrients due to the integrated application of biochar and lime, which resulted in improved soil health, enhanced plant growth, and reduced chemical fertilizer practice; this improved water holding capacity and modified soil structure (Trupiano et al., 2017). However, in many instances, the separate biochar application did not supply a considerable volume of nutrients (Glaser and Birk, 2012).

When $\mathrm{pH}$ is $<5$ in a soil solution, the $\mathrm{Al}$ ion concentration strongly influences the plant roots. This soil level comprises $40 \%$ or more of the potentially arable land worldwide. The toxicity of $\mathrm{Al}$ is one of the key drivers that stimulate plant root development. The restriction of cell division and cell extension of root development is responsible for Al toxicity in acidic soil (Zhang et al., 2007). In an Ultisol, growing maize restricted more than $60 \%$ of saturated Al; for this reason, cell division and elongation are obstructed due to the inhibition of root growth by a high $\mathrm{Al}$ concentration in acidic soils (Rabileh, 2014; Rabileh et al., 2015). The N and P deficiencies and Al toxicity decreased maize yield by 30\%, 28\%, and $16 \%$, respectively, in Kenyan soils as reported by Kisinyo (2016). Major et al. (2010) reported the impact of the dietary value and yield of maize in a savanna Oxisol in Colombia. The application studied a substantial reduction of exchangeable $\mathrm{Al}$ and $\mathrm{Fe}$ at rates of 8 and $20 \mathrm{tha}^{-1}$.

Rabileh et al. (2015) indicated that the value of soil $\mathrm{pH}$ increased from 4.82 to 5.17 by applying the empty fruit bunches (EFB) of palm oil biochar at an increasing rate of 5 to $10 \mathrm{t} \mathrm{ha}^{-1}$, respectively. The biochar $\mathrm{pH}$ was approximately 9; it therefore helped increase soil $\mathrm{pH}$. They also found that, with or without lime application, CEC significantly increased when applying EFB biochar. The CEC value increased from 13.30 to $15.30 \mathrm{cmol}_{\mathrm{c} \mathrm{kg}}{ }^{-1}$ when applying 10 to $20 \mathrm{t} \mathrm{ha}^{-1} \mathrm{EFB}$ biochar, respectively. In a maize plot, soil available P increased by $28 \%$ when applying biochar (Widowati et al., 2012). Nigussie et al. (2012) indicated the same result and mentioned that available $\mathrm{P}$ increased by $10 \mathrm{t} \mathrm{ha}^{-1}$ in garden lettuce when applying maize stalk biochar. Adding 10\% biochar increased the soil P concentration from 81.8 to $445 \mathrm{mg} \mathrm{kg}^{-1}$ (Fellet et al., 2011), and according to Widowati and Asnah (2014), the P concentration significantly increased by $179 \%$ to $208 \%$ for biochar application. By applying 10 and $20 \mathrm{t} \mathrm{ha}^{-1}$ biochar, soil exchangeable $\mathrm{K}$ increased from $64.30 \%$ to $111.57 \%$, respectively, compared with the control soil. The control soil without biochar exhibited the lowest soil exchangeable $\mathrm{K}$, approximately $10.98 \mathrm{mg} \mathrm{kg}^{-1}$ (Zaidun et al., 2019). In soil treated with urea and 20 and $40 \mathrm{t} \mathrm{ha}^{-1}$ biochar, Zhang et al. (2011) indicated increased SOC from $25 \%$ to $42 \%$, respectively, compared with the control. In the same experiment, without the addition of urea, SOC increased from $44 \%$ to $58 \%$ when applying 20 and $40 \mathrm{t} \mathrm{ha}^{-1}$ biochar, respectively.

\section{Effect of biochar on maize growth and grain yield}

Parameters related to $\mathrm{pH}$, base saturation, exchangeable $\mathrm{K}$, and $\mathrm{Ca} / \mathrm{Al}$ ratio were mostly responsible for crop yield. Soil acidification mitigated by cocoa shell biochar in an Ultisol had a beneficial impact on crop yield. Applying $15 \mathrm{t}$ ha $^{-1}$ cocoa shell biochar every third season sustained soil quality and increased yield (Yargholi and Azarneshan, 2014). The study of a savanna Oxisol in Colombia reported that maize yield increased from $28 \%$ to $140 \%$ as compared with the untreated soil 2 to $4 \mathrm{yr}$ after applying $20 \mathrm{t} \mathrm{ha}^{-1}$ biochar (Major et al., 2010). Plant leaf number and size decreased because of moisture deficiencies throughout the growing season, which reduced grain yield when the photosynthesis rate decreased (Lobell et al., 2013). Major et al. (2010) reported a Colombian savanna soil using biochar at a rate of 8 and $20 \mathrm{tha}^{-1}$ that reduced exchangeable $\mathrm{Al}$ and $\mathrm{Fe}$ and significantly increased maize yield. In acidic soils, biochar-treated soil increased soil $\mathrm{pH}$ and nutrient availability and decreased phytotoxic $\mathrm{Al}$; it has been recommended to increase crop 
yield (Kookana et al., 2011). The damage of $\mathrm{Ca}^{2+}, \mathrm{K}^{+}$, and $\mathrm{Mg}^{2+}$ from the root cells and the rupture of the cell wall are responsible for $\mathrm{Al}$ toxicity, but a low $\mathrm{Al}$ rate influenced leaf growth, which prevented the growth of maize roots (Wang et al., 2015). Biochar application at 20 and $40 \mathrm{t} \mathrm{ha}^{-1}$ without $\mathrm{N}$ fertilizer increased maize yield by $15.8 \%$ and $7.3 \%$, respectively, and it increased by $8.8 \%$ and $12.1 \%$, respectively, when combined with $\mathrm{N}$ fertilizer (Zhang et al., 2011).

The response of maize DM increased by $3 \%$ for every $\mathrm{g} \mathrm{kg}^{-1}$ biochar-treated soil with or without fertilizer (Syuhada et al., 2016). These authors also reported that maize height increased $2.45 \mathrm{~cm}$ for every $\mathrm{g} \mathrm{kg}^{-1}$ of biochar added. There was no substantial change when applying biochar at the low rate of $5 \mathrm{~g} \mathrm{~kg}^{-1}$, but change was detected at the higher rates of 10 and $15 \mathrm{~g} \mathrm{~kg}^{-1}$. Maize yield and growth usually increased with the combined application of biochar and fertilizer compared with only applying biochar. In sandy soil, maize DM remarkably increased by applying biochar processed from cow manure incorporated with chemical fertilizer compared with only applying chemical fertilizer. However, there was no change at a low rate $\left(10 \mathrm{t} \mathrm{ha}^{-1}\right)$ (Uzoma et al., 2011). These authors also explained that the application of biochar at the higher rates of 15 and $20 \mathrm{tha}^{-1}$ increased maize grain yield by $150 \%$ and $88 \%$, respectively, compared with an untreated plot.

There was a significant $(\mathrm{P}<0.05)$ increase in maize height and grain yield due to biochar application compared with the control (Njoku et al., 2016). These authors also detected that increased biochar rates increased maize grain yield and height. They reported that biochar-treated plots ranged from 600.0 to $666.67 \mathrm{~kg} \mathrm{ha}^{-1}$ maize grain yield, whereas 511.11 $\mathrm{kg} \mathrm{ha}^{-1}$ was observed in the control. Likewise, the lowest maize height value was recorded in the control at $109.50 \mathrm{~cm}$. This experimental value in the control was less than maize height by $27 \%, 42 \%$, and $81 \%$. Among the different maize parameters, ear length is a vital parameter that contributes to yield; it significantly influences both the number of grains per ear and the size of the maize grain yield. Thousand-grain weight is essential among the numerous parameters promoting the commercial maize yield (Yigermal et al., 2019).

\section{CONCLUSIONS}

The rapid growth of the world population creates pressure on limited natural resources. The use of biochar undoubtedly plays a vital role in sustainable crop production, soil health restoration, and climate change mitigation. Biochar has established a clear and substantial positive effect by supplying essential nutrients, increasing soil physicochemical properties such as $\mathrm{pH}$, cation exchange capacity, water retention capacity, and influencing microbial soil activity. However, it has been pointed out that the biochar treatment has been widely studied as a prospective technology, and the application rate is no less important. Many aspects of biochar and lime application on $\mathrm{CO}_{2}$ emission mitigation and increased maize yield still need further study because existing results are inadequate and inconsistent.

\section{ACKNOWLEDGEMENTS}

This review was supported by the Universiti Putra Malaysia (Vote No. 6282512-10201) and National Agricultural Technology Programme (NATP): Phase-II Project, Bangladesh Agricultural Research Council.

\section{REFERENCES}

Agegnehu, G., Adrian, M.B., Paul, N.N., and Michael, I.B. 2016. Benefits of biochar, compost and biocharcompost for soil quality, maize yield and greenhouse gas emissions in a tropical agricultural soil. Science of the Total Environment 543:295-306.

Ajema, L. 2018. Effects of biochar application on beneficial soil organism review. International Journal of Research Studies in Science, Engineering and Technology 5(5):9-18.

Asmare, M., and Markku, Y. 2016. Effects of applications of lime, wood ash, manure and mineral P fertilizer on the inorganic P fractions and other selected soil chemical properties on acid soil of Farta District, Northwestern highland of Ethiopia. African Journal of Agricultural Research 11(2):87-99.

Atkinson, C.J., Fitzgerald, J.D., and Hipps, N. 2010. Potential mechanisms for achieving agricultural benefits from biochar application to temperate soils: a review. Plant and Soil 337:1-18.

Beesley, L., Moreno-Jimenez, E., Gomez-Eyles, J.L., Harris, E., Robinson, B., and Sizmur, T. 2011. A review of biochars' potential role in the remediation, revegetation and restoration of contaminated soils. Environmental Pollution 159:3269-3282. 
Belic, D.S. 2006. Global warming and greenhouse gases. Facta Universitatis. Series: Physics, Chemistry and Technology 4(1):45-55.

Beluri, K., Pullagurala, V., Bojeong, K., Sang, S., Sudhir, K., and Ki-Hyun, K. 2018. Benefits and limitations of biochar amendment in agricultural soils: A review. Journal of Environmental Management 227:146-154.

Bird, M.I. 2015. Test procedures for biochar analysis in soils. p. 677-714. In Lehmann, J., and Joseph, S. (eds.) Biochar for environmental management: Science, technology and implementation. $2^{\text {nd }}$ ed. Routledge, London, UK.

Bolan, N.S., Adriano, D.C., Kunhikrishnan, A., James, T., McDowell, R., and Senesi, N. 2011. Dissolved organic matter: biogeochemistry, dynamics, and environmental significance in soils. Advances in Agronomy 110:1-75.

Cayuela, M.L., Sánchez-Monedero M.A., Roig, A., Hanley, K., Enders, A., and Lehmann, J. 2013. Biochar and denitrification in soils: when, how much and why does biochar reduce $\mathrm{N}_{2} \mathrm{O}$ emissions? Scientific Reports 3:1732.

Cayuela, M., Van Zwieten, L., Singh, B.S., Roig, A., and Sánchez-Monedero, M. 2014. Biochar's role in mitigating soil nitrous oxide emissions: A review and meta-analysis. Agriculture, Ecosystems \& Environment 191:5-16.

Cely, P., Tarquis, A.M., Pazferreiro, J., Méndez, A., and Gascó, G. 2014. Factors driving the carbon mineralization priming effect in a sandy loam soil amended with different types of biochar. Solid Earth 6:1748-1761.

Cornelissen, G., Martinsen, V., Shitumbanuma, V., Alling, V., Breedveld, G.D., Rutherford, D.W., et al. 2013. Biochar effect on maize yield and soil characteristics in five conservation farming sites in Zambia. Agronomy 3(2):256-274.

Dhadli, H.S., and Brar, B.S. 2016. Effect of long-term differential application of inorganic fertilizers and manure on soil $\mathrm{CO}_{2}$ emissions. Plant, Soil and Environment 62:195-201.

Domene, X., Mattana, S., Hanley, K., Enders, A., and Lehmann, J. 2014. Medium-term effects of corn biochar addition on soil biota activities and functions in a temperate soil cropped to corn. Soil Biology and Biochemistry 72:152-162.

EPA. 2009-2012. United States greenhouse emission gases. Environmental Protection Agency (EPA), Washington D.C., USA.

Fellet, G., Marchiol, L., Delle Vedova, G., and Peressotti, A. 2011. Application of biochar on mine tailings: Effects and perspectives for land reclamation. Chemosphere 83(9):1262-1267.

Glaser, B., and Birk, J. 2012. State of the scientific knowledge on properties and genesis of Anthropogenic Dark Earths in Central Amazonia (terra preta de Índio). Geochimica et Cosmochimica Acta 82:39-51.

Gonzaga, M.I.S., Mackowiak, C., Almeida, A.Q., Carvalho, J.I.T., and Andrade, K.R. 2018. Positive and negative effects of biochar from coconut husks, orange bagasse and pine wood chips on maize (Zea mays L.) growth and nutrition. CATENA 162:414-420.

Han, Y., Chen, X., Wang, E., and Xia, X. 2019. Optimum biochar preparations enhance phosphorus availability in amended Mollisols of Northeast China. Chilean Journal of Agricultural Research 79:153-164. doi:10.4067/S0718-58392019000100153.

He, Y., Zhou, X., Jiang, L., Li, M., Du, Z., Zhou, G., et al. 2016. Effects of biochar application on soil greenhouse gas fluxes: a meta-analysis. GCB Bioenergy 9:743-755.

Ibrahim, M.E.H., Ali, A.Y.A., Zhou, G., Elsiddig, A.M.I., Zhu, G., Nimir, N.E.A., et al. 2020. Biochar application affects forage sorghum under salinity stress. Chilean Journal of Agricultural Research 80:317325. doi.org/10.4067/S0718-58392020000300317.

Jeffery, S., Abalos, D., Prodana, M., Bastos, A.C., van Groenigen, J.W., Hungate, B.A., et al. 2017. Biochar boosts tropical but not temperate crop yields. Environmental Research Letter 12:053001. https://doi.org/10.1088/1748-9326/aa67bd.

Jeffery, S., Verheijen, F.G., van der Velde, M., and Bastos, C. 2011. A quantitative review of the effects of biochar application to soils on crop productivity using meta-analysis. Agriculture, Ecosystems \& Environment 144:175-187.

Joris, H.A.W., Caires, E.F., Bini, A.R., Scharr, D.A., and Haliski, A. 2013. Effects of soil acidity and water stress on corn and soybean performance under a no-till system. Plant and Soil 365:409-424.

Kameyama, K., Miyamoto, T., Iwata, Y., and Shiono, T. 2016. Influences of feedstock and pyrolysis temperature on the nitrate adsorption of biochar. Soil Science and Plant Nutrition 62(2):180-184.

Kammann, C., Ratering, S., Eckhard, C., and Müller, C. 2012. Biochar and hydrochar effects on greenhouse gas $\left(\mathrm{CO}_{2}, \mathrm{~N}_{2} \mathrm{O}\right.$, $\mathrm{CH}_{4}$ ) fluxes from soils. Journal of Environmental Quality 41:1052-1066.

Kijewska, A., and Bluszcz, A. 2016. Analysis of greenhouse gas emissions in the European Union member states with the use of an agglomeration algorithm. Journal of Sustainable Mining 15:133-142.

Kisinyo, P.O. 2016. Effect of lime and phosphorus fertilizer on soil chemistry and maize seedlings performance on Kenyan acid soils. Sky Journal of Agricultural Research 5(6):97-104.

Kookana, R.S., Sarmah, A.K., Zwieten, L., Van Krull, E., and Singh, B. 2011. Biochar application to soil: Agronomic and environmental benefits and unintended consequences. Advances in Agronomy 112:103-143.

Kumar, D., and Jhariya, N.A. 2013. Nutritional, medicinal and economical importance of corn: A mini-review. Research Journal of Pharmaceutical Sciences 2:7-8.

Kuzyakov, Y., Subbotina, I., Chen, H., Bogomolova, I., and Xu, X. 2009. Black carbon decomposition and incorporation into soil microbial biomass estimated by ${ }^{14} \mathrm{C}$ labeling. Soil Biology and Biochemistry 41(2):210-219.

Kweku, D.W., Bismark, O., Maxwell, A., Desmond, K.A., Danso, K.B., Oti-Mensah, E.A., et al. 2017. Greenhouse effect: Greenhouse gases and their impact on global warming. Journal of Scientific Research and Reports 17(6):JSRR.39630. 
Lal, R. 2011. Sequestering carbon in soils of agro-ecosystems. Food Policy 36:S33-S39.

Lehmann, J., and Joseph, S. 2009. Biochar for environmental management: an introduction. p. 1-12. In Lehmann, J., and Joseph, S. (eds.) Biochar for environmental management, science and technology. Earthscan, London, UK.

Lehmann, J., Rillig, M.C., Thies, J., Masiello, C.A., Hockaday, W.C., and Crowley, D. 2011. Biochar effects on soil biota - A review. Soil Biology and Biochemistry 43:1812-1836.

Leonard, P. 2012. pH for the garden handbook 18. Soil Conservation Service, U.S. Department of Agriculture, Washington D.C., USA.

Liu, X., Zhang, A., Ji, C., Joseph, S., Bian, R., Li, L., et al. 2013. Biochar's effect on crop productivity and the dependence on experimental conditions - a meta-analysis of literature data. Plant and Soil 373:583-594.

Liu, Y., Yang, M., Wu, Y., Wang, H., Chen, Y., and Wu, W. 2011. Reducing $\mathrm{CH}_{4}$ and $\mathrm{CO}_{2}$ emissions from waterlogged paddy soil with biochar. Journal of Soils and Sediments 11:930-939.

Lobell, D.B., Hammer, G.L., McLean, G., Messina, C., Roberts, M.J., and Schlenker, W. 2013. The critical role of extreme heat for maize production in the United States. Nature Climate Change 3(5):497-501.

Luo, Y., Durenkamp, M., Nobili, M.D., Lin, Q., and Brookes, P.C. 2011. Short term soil priming effects and the mineralisation of biochar following its incorporation to soils of different pH. Soil Biology and Biochemistry 43:2304-2314.

Major, J., Rondon, M., Molina, D., Riha, S.J., and Lehmann, J. 2010. Maize yield and nutrition during 4 years after biochar application to a Colombian savanna Oxisol. Plant and Soil 333:117-128.

Mandal, S., Sarkar, B., Bolan, N., Novak, J., Ok, Y.S., Van Zwieten, L., et al. 2016. Designing advanced biochar products for maximizing greenhouse gas mitigation potential. Critical Reviews in Environmental Science and Technology 46:1367-1401.

Mensah, A.K., and Frimpong, K.A. 2018. Biochar and/or compost applications improve soil properties, growth, and yield of maize grown in acidic rainforest and coastal savannah soils in Ghana. International Journal of Agronomy 2018:ID6837404. doi:10.1155/2018/6837404.

Mwangi, T.J., Ngeny, J.M., Wekesa, F., and Mulati, J. 2000. Acidic soil amendment for maize production in Uasin Gishu District, North Rift Kenya. Kenya Agricultural Research Institute, National Agricultural Research Centre, Kitale, Kenya.

Nigussie, A., Kissi, E., Misaganaw, M., and Ambaw, G. 2012. Effects of biochar application on soil properties and nutrient uptake of lettuces (Lactuca sativa) grown in polluted soils. American-Eurasian Journal of Agriculture and Environmental Science 12(3):369-376.

Njoku, C., Uguru, B.N., and Chibuike, C.C. 2016. Use of biochar to improve selected soil chemical properties, carbon storage and maize yield in an Ultisol in Abakaliki Ebonyi State, Nigeria. International Journal of Environmental and Agriculture Research 2(1):15-22.

Novotny, E.H., Maia, C.M.B. de F., Carvalho, M.T. de M., and Madari, B.E. 2015. Biochar: Pyrogenic carbon for agricultural use - A critical review. Revista Brasileira de Ciencia do Solo 39:321-344.

Nuss, E.T., and Tanumihardjo, S.A. 2010. Maize: A paramount staple crop in the context of global nutrition. Comprehensive Reviews in Food Science and Food Safety 9:417-436. doi:10.1111/j.1541-4337.2010.00117.x.

Onwuka, M.I., Osodeke, V.E., and Ano, A.O. 2009. Use of liming materials to reduce soil acidity and affect maize (Zea mays L) growth parameters in Umudike, Southeast Nigeria. Production Agriculture and Technology 5(2):386-396.

Oo, A.Z., Sudo, S., Akiyama H., Win, K.T., Shibata, A., Yamamoto, A., et al. 2018. Effect of dolomite and biochar addition on $\mathrm{N}_{2} \mathrm{O}$ and $\mathrm{CO}_{2}$ emissions from acidic tea field soil. PLOS ONE 13(2):e0192235. https://doi.org/10.1371/journal.pone.0192235.

Opala, P.A. 2017. Influence of lime and phosphorus application rates on growth of maize in an acid soil. Advances in Agriculture 2017:ID7083206. https://doi.org/10.1155/2017/7083206.

Opala, P.A., Odendo, M., and Muyekho, F.N. 2018. Effects of lime and fertilizer on soil properties and maize yields in acid soils of Western Kenya. African Journal of Agricultural Research 13:657-663.

Rabileh, M.A. 2014. Alleviation of soil acidity and aluminum toxicity in Ultisol using biochar for maize cultivation. MSc. Thesis. Universiti Putra Malaysia, Selangor, Malaysia.

Rabileh, M.A., Shamshuddin, J., Panhwar, Q.A., Rosenani, A.B., and Anuar, A.R. 2015. Effects of biochar and/or dolomitic limestone application on the properties of Ultisol cropped to maize under glasshouse conditions. Canadian Journal of Soil Science 95:37-47. doi:10.4141/CJSS-2014-067.

Shaaban, M., Peng, Q., Hu, R., Lin, S., Wu. Y., and Ullah, B. 2014. Dissolved organic carbon and nitrogen mineralization strongly affect $\mathrm{CO}_{2}$ emissions following lime application to acidic soil. Journal of the Chemical Society of Pakistan 36:875-879.

Shaaban, M., Peng, Q., Hu, R., Wu, Y., Lin, S., and Zhao, J. 2015. Dolomite application to acidic soils: a promising option for mitigating $\mathrm{N}_{2} \mathrm{O}$ emissions. Environmental Science and Pollution Research 22(24):19961-19970. doi:10.1007/s11356-0155238-4.

Shaaban, M., Wu, Y., Peng, Q., Lin, S., Mo, Y., Wu, L., et al. 2016. Effects of dicyandiamide and dolomite application on $\mathrm{N}_{2} \mathrm{O}$ emission from an acidic soil. Environmental Science and Pollution Research 23:6334-6342. doi:10.1007/s11356-015-5863-y.

Shah, T.R., Prasad, K., and Kumar, P. 2016. Maize - A potential source of human nutrition and health: A review. Cogent Food \& Agriculture 2(1):1166995

Shen, J., Tang, H., Liu, J., Wang, C., Li, Y., Ge, T., et al. 2014. Contrasting effects of straw and straw-derived biochar amendments on greenhouse gas emissions within double rice cropping systems. Agriculture, Ecosystems and Environment 188:264-274. 
Shen, Y., Zhu, L., Cheng, H., Yue, S., and Li, S. 2017. Effects of biochar application on $\mathrm{CO}_{2}$ emissions from a cultivated soil under semiarid climate conditions in Northwest China. Sustainability 9:1482.

Singh, B.P., and Cowie, A.L. 2014. Long-term influence of biochar on native organic carbon mineralisation in a low-carbon clayey soil. Scientific Reports 4:3687.

Slapakova, B., Jerabkova, V., and Tejnecky, D.O. 2018. The biochar effect on soil respiration and nitrification. Plant, Soil and Environment 64(3):114-119.

Sohi, S., Krull, E., Lopez-Capel, E., and Bol, R. 2010. A review of biochar and its use and function in soil. Advances in Agronomy 105:47-82.

Somchai, B., Jonathan L.D., Banyong, T., Michael J.A., and Patma, V. 2014. Biochar characteristics and application rates affecting corn growth and properties of soils contrasting in texture and mineralogy. Geoderma 237-238:105-116.

Song, X., Pan, G.,Zhang, C., Zhang, L., and Wang, H. 2016. Effects of biochar application on fluxes of three biogenic greenhouse gases: A meta-analysis. Ecosystem Health and Sustainability 2(2):e01202.

Spokas, K.A., and Reicosky, D.C. 2009. Impacts of sixteen different biochars on soil greenhouse gas production. Annals of Environmental Science 3:179-193.

Stepniewska, Z., and Kuzniar, A. 2013. Endophytic microorganisms- promising applications in bioremediation of greenhouse gases. Applied Microbiology and Biotechnology 97:9589-9596.

Syuhada, A.B., Shamshuddin, J., Fauziah, C.I., Rosenani, A.B., and Arifin, A. 2016. Biochar as soil amendment: Impact on chemical properties and corn nutrient uptake in a Podzol. Canadian Journal of Soil Science 96:400-412. doi:10.1139/CJSS-2015-0044.

Taghizadeh-Toosi,A.,Clough,T.J.,Condron,L.M., Sherlock, R.R.,Anderson,C.R., and Craigie,R.A.2011.Biochar incorporation into pasture soil suppresses in situ nitrous oxide emissions from ruminant urine patches. Journal of Environmental Quality 40(2):468-476.

Thies, J., and Rillig, M. 2009. Characteristics of biochar: biological properties. p. 85-102. In Lehmann, J., and Joseph, S. (eds.) Biochar for environmental management. Earthscan, London, UK.

Trupiano, D., Cocozza, C.S., and Baronti, S. 2017. The effects of biochar and its combination with compost on lettuce (Lactuca sativa L.) growth, soil properties, and soil microbial activity and abundance. Hindawi International Journal of Agronomy 2017:ID3158207.

Uzoma, K.C., Inoue, M., Andry, H., Fujimaki, H., Zahoor, A., and Nishihara, E. 2011. Effect of cow manure biochar on maize productivity under sandy soil conditions. Soil Use and Management 27:205-212.

Ventura, M., Sorrenti, G., Panzacchi, P., George, E., and Tonon, G. 2013. Biochar reduces short-term nitrate leaching from a horizon in an apple orchard. Journal of Environmental Quality 42:76-82.

Wahab, A.G., and Rittgers, C. 2014. Malaysia: Grain and feed annual 2014. Global Agricultural Information Network, USDA Foreign Agricultural Service, Washington, D.C., USA. Available at http://agriexchange.apeda.gov.in/MarketReport/Reports/ Grain_and_Feed_Annual_Kuala_Lumpur_Malaysia_2-14-2014.pdf (accessed 26 January 2018).

Wang, L., Fan, X., Pan, J., Huang, Z., and Li, Y.2015. Physiological characterization of maize tolerance to low dose of aluminum, highlighted by promoted leaf growth. Planta 242:1391-1403. doi:10.1007/s00425-015-2376-3.

Weng, Z., Van Zwieten, L., Singh, B.P., Tavakkoli, E., Joseph, S., Macdonald, L.M., et al. 2017. Biochar built carbon over a decade by stabilizing rhizodeposits. Nature Climate Change 7:371-376.

Widowati, W., and Asnah, A. 2014. Biochar can enhance potassium fertilization efficiency and economic feasibility of maize cultivation. Journal of Agricultural Science 6(2):24-32.

Widowati, W., Utomo, W.H., Guritno, B., and Soehono, L.A. 2012. The effects of biochar on the growth and N fertilizer requirement of maize (Zea mays L.) in green house experiment. Journal of Agricultural Science 4(5):255-262.

Wu, D., Senbayram, M., Zang, H., Ugurlar, F., Aydemir, S., Bruggemann, N., et al. 2018. Effect of biochar origin and soil pH on greenhouse gas emissions from sandy and clay soils. Applied Soil Ecology 129:121-127.

Xiubin, W., Dali, S., Guoqing, L., Qian, Z., Chao, A., and Wei, Z. 2015. Maize biochar addition rate influences soil enzyme activity and microbial community composition in a fluvo-aquic soil. Applied Soil Ecology 96:265-272.

Yagi, R., Fidalski, J., and Tormena, C.A. 2014. The incorporation of limestone in consolidated no-tillage system reduces carbon stock in soil macroaggregates. Ciência Rural, Santa Maria 44(11):1962-1965. http://dx.doi.org/10.1590/0103-8478cr20140339.

Yao, L., Yu, X., Huang, L., Zhang, X., Wang, D., Zhao, X., et al. 2019. Responses of Phaseolus calcaltus to lime and biochar application in an acid soil. PeerJ 7:e6346. https://doi.org/10.7717/peerj.6346.

Yargholi, B., and Azarneshan, S. 2014. Long-term effects of pesticides and chemical fertilizers usage on some soil properties and accumulation of heavy metals in the soil (case study of Moghan plain's (Iran) irrigation and drainage network). International Journal of Agriculture and Crop Sciences 7(8):518-523.

Yigermal, H., Nakachew, K., and Assefa, F. 2019. Effects of integrated nutrient application on phenological, vegetative growth, and yield-related parameters of maize in Ethiopia: A review. Cogent Food \& Agriculture 5:1567998. https://doi.org/10.1080/23311932.2019.1567998. 
Yoo, J., Woo, S.H., Park, K.D., and Chung, K.Y. 2016. Effect of no-tillage and conventional tillage practices on the nitrous oxide $\left(\mathrm{N}_{2} \mathrm{O}\right)$ emissions in an upland soil: soil $\mathrm{N}_{2} \mathrm{O}$ emission as affected by the fertilizer applications. Applied Biological Chemistry 59(6):787-797. doi:10.1007/s13765-016-0226-z.

Zafar, U., Akmal, M., Ahmed, M., Ali, M., and Jamali, A.Z. 2018. Effect of biochar on soil chemical properties and nutrient availability in sandstone and shale derived soils. Journal of Biodiversity and Environmental Sciences 12(5):272-277.

Zaidun, S.W., Jalloh, M.B., Awang, A., Sam, L.M., Besar, N.A., Musta, B., et al. 2019. Biochar and clinoptilolite zeolite on selected chemical properties of soil cultivated with maize (Zea mays L.) Eurasian Journal of Soil Science 8(1):1-10.

Zhang, J., He, Z., Tian, H., Zhu, G., and Peng, X. 2007. Identification of aluminium-responsive genes in rice cultivars with different aluminium sensitiveness. Journal of Experimental Botany 58:2269-2278.

Zhang, A., Liu, Y., Pan, G., Hussain, Q., Li, L., Zheng, J., et al. 2011. Effect of biochar amendment on maize yield and greenhouse gas emissions from a soil organic carbon poor calcareous loamy soil from Central China Plain. Plant and Soil 351(1-2):263-275.

Zhang, D., Pan, G., Wu, G., Kibue, G.W., Li, L., Zhang, X., et al. 2016. Biochar helps enhance maize productivity and reduce greenhouse gas emissions under balanced fertilization in a rainfed low fertility Inceptisol. Chemosphere 142:106-113.

Zhu, Q., Kong, L., Xie, F., Zhang, H., Wang, H., and Ao, X. 2018. Effects of biochar on seedling root growth of soybeans. Chilean Journal of Agricultural Research 78:549-558. doi:10.4067/S0718-58392018000400549. 